\title{
Pengembangan Perangkat Pembelajaran Matematika Berbasis Model Problem Based Learning Untuk Memfasilitasi Kemampuan Komunikasi Matematis Peserta Didik Kelas VII SMP/MTs
}

\author{
Aisyah Nurul Rahmah ${ }^{1}$, Zulkarnain ${ }^{2}$, Nahor Murani Hutapea ${ }^{3}$ \\ 1,2,3 Program Pasca Sarjana Pendidikan Matematika, Universitas Riau, Jl. H. R. Soebrantas, Riau \\ Aisyah.nurul6789@grad.unri.ac.id
}

\begin{abstract}
This research is motivated by teachers who still have difficulty in designing learning tools based on the 2013 curriculum. This study aims to produce mathematical learning tools based on a problem-based learning model to facilitate valid and practical mathematical communication skills of students. Learning tools developed in the form of a syllabus, lesson plan (RPP), student worksheets (LKPD). The development model used is the 4-D model which stages are define, design, develop, and disseminate. The test subjects in this study were 8 class VII students. The test instrument used was a validity instrument in the form of a validation sheet to assess the appropriateness of the learning device and a practicality instrument in the form of a student response questionnaire to assess the practicality of using LKPD. Based on the results of the validation data analysis, it is concluded that this mathematics learning tool is very valid with the average rating for the syllabus is $89.81 \%$, for RPP is $92.43 \%$, for LKPD is $90.85 \%$. Based on the results of the practicality data analysis, the student response questionnaire showed a very practical category with an average assessment of $89.80 \%$.
\end{abstract}

Keywords: Learning Tools, Students' Mathematical Communication Skills, Problem Based Learning Model

\begin{abstract}
Abstrak
Penelitian ini dilatarbelakangi oleh guru yang masih kesulitan dalam merancang perangkat pembelajaran berdasarkan kurikulum 2013. Tujuan penelitian adalah menghasilkan perangkat pembelajaran matematika berbasis model problem based learning untuk memfasilitasi kemampuan komunikasi matematis peserta didik yang valid dan praktis. Perangkat pembelajaran yang dikembangkan berupa silabus, rencana pelaksanaan pembelajaran (RPP), lembar kerja peserta didik (LKPD). Model pengembangan yang digunakan adalah model 4-D yang tahapannya yaitu define, design, develop, dan disseminate. Subjek ujicoba dalam penelitian ini adalah 8 orang peserta didik kelas VII. Instrumen tes yang digunakan pada penelitian ini adalah instrumen validitas berupa lembar validasi untuk menilai kelayakan perangkat pembelajaran serta instrument praktikalitas berupa angket respon peserta didik untuk menilai kepraktisan penggunaan LKPD. Berdasarkan hasil analisis data validasi disimpulkan bahwa perangkat pembelajaran matematika ini sangat valid dengan rata-rata penilaian untuk silabus adalah 89,81\%, untuk RPP adalah 92,43\%, untuk LKPD adalah 90,85\%. Berdasarkan hasil analisis data kepraktisan angket respon peserta didik menunjukkan kategori sangat praktis dengan ratarata penilaian $89,80 \%$.
\end{abstract}

Kata kunci: Perangkat Pembelajaran, Kemampuan Komunikasi Matematis, Model Problem Based Learning

Copyright (c) 2021 Aisyah Nurul Rahmah, Zulkarnain, Nahor Murani Hutapea

$\triangle$ Corresponding author: Aisyah Nurul Rahmah

Email Address: aisyah.nurul6789@grad.unri.ac.id (Jl. H.R Soebrantas, Riau)

Received 10 September 2020, Accepted 21 September 2020, Published 14 Februari 2021

\section{PENDAHULUAN}

Peraturan Pemerintah No 19 Tahun 2005 menyatakan bahwa ketercapaian tujuan pembelajaran matematika tergantung pada peran satuan pendidikan dalam menyiapkan dan melaksanakan suatu perencanaan, pelaksanaan, penilaian, dan pengawasan pembelajaran demi terlaksananya proses pembelajaran yang efektif dan efisien. Untuk itu perlu mempersiapkan perencanaan, pelaksanaan dan penilaian proses pembelajaran agar Standar Kompetensi Lulusan (SKL) dapat tercapai. 
Perencanaan pembelajaran dilakukan dengan mempersiapkan dan mengembangkan perangkat pembelajaran merupakan perencanaan dari suatu pembelajaran. Menurutu (Akbar, 2013) keterlaksanaan kurikulum sangat ditentukan oleh kemampuan guru dalam mengembangkan perangkat pembelajaran, sebab perangkat pembelajaran tersebut diimplementasikan dalam praktik pembelajaran sehari-hari di satuan pendidikan. Seorang guru dalam proses pembelajaran perlu mempersiapkan perangkat pembelajaran sebagai sarana untuk memudahkan peserta didik dalam memahami materi matematika yang disajikan, sekaligus memudahkan pendidik dalam menerapkan standar kompetensi lulusan (Permendikbud No 54 Tahun 2013).

(Armis \& Suhermi, 2017) menyatakan silabus, rencana pelaksanaan pembelajaran (RPP), lembar kerja peserta didik (LKPD), instrumen penilaian, media pembelajaran merupakan perangkat pembelajaran. Menurut (Trianto, 2009) menjelaskan bahwa guru harus merancang perangkat pembelajaran yang digunakannya, untuk mencapai tujuan pembelajaran di kelas. Selanjutnya, (Tanjung \& Nababan, 2018) menyatakan bahwa setiap guru berkewajiban menyusun perangkat pembelajaran secara lengkap dan sistematis agar pembelajaran berlangsung secara interaktif, inspiratif, menyenangkan, menantang dan memotivasi siswa untuk berpartisipasi aktif

Faktanya dilapangan menunjukkan bahwa, (Rianti, Saragih, \& Zulkarnain, 2020) menyatakan guru kesulitan mengembangkan silabus dan RPP sesuai dengan kurikulum 2013, dan guru juga kesulitan menyusun LKPD yang mendorong siswa memahami materi dan menemukan konsep sendiri. Hal ini sejalan dengan (Frisnoiry, Armanto, \& Sumarno, 2014) menyatakan bahwa LKPD yang digunakan oleh guru belum menciptakan peserta didik yang aktif dan LKPD tidak dapat menanamkan konsep materi pelajaran. Menurut (Fitri, Yuanita, \& Maimunah, 2020) menyatakan guru menggunakan perangkat pembelajaran yang berasal dari penerbit, unggahan media internet dan dari hasil MGMP.

Menurut (Yustianingsih, Syarifuddin, \& Yerizon, 2017) menyatakan RPP yang digunakan tidak mengarahkan peserta didik aktif dalam pembelajaran serta tidak mengkontruksi pengetahuannya. LKPD yang digunakan hanya pemberian materi berbentuk rumus langsung, sehingga tidak dapat memahmi konsep yang dipelajari. Menurut (Fitriani, Hartono, \& Purwoko, 2010) menyatakan RPP yang digunakan duplikasi dari sekolah lain, dan langkah pembelajaran yang digunakan masih konvensional.

Menurut (Radeswandri, 2016) dalam penelitiannya yang menyatakan terdapat beberapa masalah guru dalam merancang perangkat pembelajaran yaitu (1) guru kesulitan merancang perangkat pembelajaran, karena sekolah baru mengimplementasikan kurikulum 2013; (2) perangkat pembelajaran berpusat pada guru, padahal kurikulum 2013 menuntut peserta didik aktif; (3) guru sulit merancang perangkat pembelajaran, sehingga guru melihat contoh perangkat yang di internet atau MGMP. Guru harus dapat merancang dan menyusun RPP dengan sistematis dan lengkap, sehingga tercipta pembelajaran yang interaktif, inspiratif, menyenangkan, menantang, efisien, memotivasi peserta didik agar berpartisipasi aktif, serta merencanakan ruang yang cukup untuk perkembangan 
Pengembangan Perangkat Pembelajaran Matematika Berbasis Model Problem Based Learning Untuk Memfasilitasi Kemampuan Komunikasi Matematis Peserta Didik Kelas VII SMP/MTs, Aisyah Nurul Rahmah, Zulkarnain, Nahor Murani Hutapea

fisik serta psikologis (Permendikbud Nomor 22 Tahun 2016).

Peneliti melakukan observasi dan wawancara dengan beberapa orang guru matematika SMP di kota Pekanbaru meliputi aspek keterlibatan guru dalam merancang perangkat pembelajaran yang digunakan dalam pembelajaran. Hasil wawancara diperoleh informasi bahwa guru belum maksimal merancang perangkat pembelajaran. RPP yang dirancang oleh guru merupakan salinan dari teman sejawat yang belum sesuai dengan kurikulum 2013. Guru sudah membuat RPP, namun RPP yang dirancang hanya menggunakan pembelajaran konvensional dengan pendekatan saintifik.

Hasil telaah dokumen ditemukan pada salah satu RPP yang digunakan guru menunjukkan bahwa pada langkah-langkah kegiatan pembelajaran masih menggambarkan proses pembelajaran yang berpusat pada guru, hal ini tidak sesuai dengan kurikulum 2013 yang menuntut peserta didik aktif dalam pembelajaran. Penilaian yang terdapat pada RPP belum jelas dan terinci dengan baik, guru kesulitan dalam membuat rencana penilaian yang dituangkan ke dalam RPP. Selanjutnya, hasil telaah pada LKPD yang digunakan oleh guru. Pada wawancara masih terdapat guru yang tidak menggunakan LKPD, tetapi ada guru yang sudah menggunakan LKPD, namun LKPD yang digunakan berasal dari penerbit. LKPD hanya berisi ringkasan materi dan pemberian rumus dan soal pada LKPD masih bersifat hitungan dan tidak berbentuk soal yang berkaitan dengan kehidupan sehari-hari.

Permendikbud Nomor 56 Tahun 2014 menyatakan bahwa tujuan pembelajaran matematika yang terdapat dalam lampiran adalah supaya para peserta didik mampu menyusun bukti matematika dengan kalimat lengkap, tabel, simbol, diagram atau media lain dan mampu mengkomunikasikan gagasan, serta penalaran. Agar tercapainya tujuan tersebut, salah satu kemampuan yang harus dikuasai adalah kemampuan komunikasi matematis peserta didik. Umar (Putra, 2016) mengemukakan bahwa kemampuan komunikasi matematis merupakan peserta didik dapat mengomunikasikan atau menyampaikan ide-idenya dalam usaha memecahkan masalah yang diberikan guru, berpartisipasi aktif dalam diskusi bertanya jawab, dan mempertanggungjawabkan jawaban mereka terhadap masalah. Menurut NCTM (Apriana, Sugiatno, \& Hamdani, 2015) menyatakan alasan pentingnya kemampuan komunikasi matematis peserta didik yaitu menyatakan bahwa komunikasi matematis dapat membantu peserta didik mengkonsolidasi dan mengorganisasi berpikir matematisnya baik secara tulisan maupun lisan, sehingga respon antar peserta didik dapat terjadi dalam proses pembelajaran.

Buhaerah (Sari \& Rahadi, 2014) mengemukakan peserta didik hanya diminta menyelesaikan soal tanpa melatih kemampuan komunikasi, sehingga membuat rendahnya kemampuan komunikasi matematis peserta didik. Menurut Baroody, Miriam, dkk (Sari \& Rahadi, 2014) mengemukakan bahwa komunikasi matematis bukan hanya menyatakan ide melalui tulisan tetapi kemampuan peserta didik dalam hal berbicara, menerangkan, menjelaskan, menggambar, menanyakan dan bekerja sama. Peserta didik sangat sulit memberikan penjelasan yang logis, tepat, dan jelas atas jawaban yang disampaikan peserta didik, hal ini karena peserta didik tidak diminta untuk menyampaikan ide 
matematika saat melaksanakan pembelajaran di sekolah. Rendahnya kemampuan komunikasi matematis pada peserta didik tergantung oleh kegiatan pembelajaran yang terjadi di kelas.

Hasil studi analisis yang telah dilakukan oleh Wardhani dan Rumiati (Noviyana, Dewi, \& Rochmad, 2019) yang menyatakan bahwa hasil TIMSS matematika di Indonesia rendah disebabkan rendahnya kemampuan peserta didik dalam menyelesaikan pertanyaan yang menuntut kemampuan, salah satu kemampuan yang dibutuhkan adalah kemampuan komunikasi matematis. (Hikmah, Roza, \& Maimunah, 2019) menyatakan bahwa peserta didik kelas VII SMP IT Riau Global Pekanbaru memiliki kemampuan komunikasi matematis yang belum berkembang secara optimal, beberapa siswa masih kesulitan bahkan tidak mampu menuliskan ide matematisnya. Tidak tercapainya kemampuan komunikasi matematis siswa disebabkan adanya beberapa hambatan dan kesulitan yang dialami siswa dalam mengkomunikasikan permasalahan matematis.

Hasil studi pendahuluan tes soal kemampuan komunikasi matematis pada materi segiempat dan segitiga diperoleh salah satu gambaran bahwa peserta didik sudah menuliskan diketahui dan ditanya, namun tidak membuat model matematikanya. Peserta didik masih kesulitan dalam menentuka ide dan konsep, namun peserta didik dapat membuat gambar dengan benar. Hal ini menunjukkan bahwa kemampuan komunikasi matematis peserta didik masih rendah.

Salah satu upaya untuk meningkatkan kemampuan komunikasi matematis yaitu menyusun kegiatan pembelajaran berfokus pada peserta didik baik secara lisan maupun tulisan. Langkah pertama yang harus diambil adalah memilih model/strategi pembelajaran dan perangkat pembelajaran yang tepat. Model problem based learning merupakan pembelajaran yang diberikan berkelompok untuk menemukan solusi dari masalah nyata secara mandiri. Guru hanya sebagai fasilitator. Model problem based learning memberikan kesempatan untuk mengembangkan kemampuan agar beradaptasi dengan situasi baru. (Fatmasuci, 2017) menyatakan model PBL merupakan alternatif dalam meningkatkan kemampuan komunikasi matematis sehingga siswa terlibat aktif bekerja kelompok, dan berani menyalurkan pendapat atau hasil diskusi kelompok dengan baik, sehingga dapat dipahami kelompok lain.

Menurut (Pansa, 2017) mengungkapkan bahwa model problem based learning dapat meningkatkan kemampuan komunikasi peserta didik dan dari hasil penelitiannya menyimpulkan bahwa LKPD dengan model problem based learning yang dikembangkan memenuhi kriteria valid, praktis, dan efektif untuk meningkatkan kemampuan komunikasi matematis. (Ridwan, Zulkardi, \& Darmawijoyo, 2016) menyatakan konsep pembelajaran berbasis masalah adalah metode yang meminta siswa untuk bekerja bersama kelompok mencari solusi dari masalah nyata. Hal ini yang mendasari peneliti memilih model problem based learning yang diharapkan dapat memberi peluang kepada siswa untuk dapat meningkatkan kemampuan komunikasi matematis peserta didik.

Berdasarkan pembahasan di atas, terdapat solusi menangani masalah yang ditemukan adalah dengan mengembangkan perangkat pembelajaran matematika menggunakan model problem based learning untuk meningkatkan kemampuan komunikasi matematis peserta didik kelas VII SMP pada 
Pengembangan Perangkat Pembelajaran Matematika Berbasis Model Problem Based Learning Untuk Memfasilitasi Kemampuan Komunikasi Matematis Peserta Didik Kelas VII SMP/MTs, Aisyah Nurul Rahmah, Zulkarnain, Nahor Murani Hutapea

materi segiempat dan segitiga.

\section{METODE}

Penelitian yang dilakukan digolongkan sebagai penelitian pengembangan dengan model 4D yang terdiri dari empat tahap pengembangan, yaitu define, design, develop, dan disseminate. Produk dari penelitian pengembangan ini adalah perangkat pembelajaran berbasis model problem based learning untuk peserta didik SMP/MTs kelas VII. Perangkat yang dikembangkan yaitu silabus, Rencana Pelaksanaan Pembelajaran (RPP) dan Lembar Kegiatan Peserta Didik (LKPD). Penelitian dilaksanakan pada bulan April 2020 di SMP Yabri Pekanbaru. Subjek uji coba dalam penelitian ini adalah dosen ahli dan peserta didik kelas VII. Subjek uji coba ini dilakukan terhadap 8 orang peserta yang mempunyai kemampuan heterogen yang diambil dari peserta didik kelas VII ${ }_{1}$ SMP Yabri Pekanbaru. Prosedur pengembangan dalam penelitian ini hanya sampai tiga tahapan karena terbatasnya waktu untuk mengumpulkan peserta didik (pandemi Covid-19), adapun tahapannya terdiri atas pendefinisian (define), perancangan (design), dan pengembangan (develop).

Pada tahap define yang dilakukan yaitu (1) analisis awal akhir bertujuan menentukan masalah dasar yang dapat digunakan dalam pengembangan bahan pembelajaran; (2) analisis peserta didik bertujuan untuk mengetahui karakteristik peserta didik sebagai subjek penelitian dan disesuaikan dengan rancangan pengembangan pembelajaran; (3) analisis tugas bertujuan untuk mengidentifikasi tugas yang akan dilakukan oleh peserta didik selama pembelajaran dan menganalisisnya; (4) analisis materi bertujuan untuk mengidentifikasi dan menyusun secara sistematis materi yang akan diajarkan berdasarkan analisis awal-akhir; (5) spesifikasi tujuan pembelajaran, dimana hasil analisis tugas dan analisis materi digunakan untuk merumuskan tujuan pembelajaran.

Pada tahap design yang dilakukan yaitu (1) penyusunan tes yaitu menyusun kisi-kisi tes hasil belajar yang berbentuk soal tes kemampuan komunikasi matematis yang sebelumnya didasarkan pada spesifikasi tujuan pembelajaran dan analisis siswa; (2) pemilihan format bertujuan untuk merancang isi, pemilihan strategi pembelajaran, pendekatan, metode pembelajaran, dan sumber belajar; (3) perancangan awal, dimana peneliti yaitu merancang silabus, RPP, dan LKPD. Pada tahap develop yang dilakukan yaitu (1) penilaian ahli, dimana perangkat pembelajaran yang telah dikembangkan peneliti di validasi oleh validator; (2) uji coba pengembangan, setelah perangkat pembelajaran valid, peneliti melakukan uji kelompok kecil untuk melihat keterbacaan LKPD. Pada tahap disseminate, yang dapat dilakukan pada penelitian ini adalah seminar hasil dan penyusunan artikel untuk publikasikan pada jurnal. 
Teknik analisis yang digunakan yaitu analisis data kualitatif berupa saran dan masukan dari validator yang berguna untuk bahan perbaikan pada tahap revisi, dan analisis kuantitatif berupa analisis validitas perangkat pembelajaran dan analisis keterbacaan perangkat pembelajaran. Data kevalidan menggunakan rumus sebagai berikut.

$V_{a}=\frac{T S e}{T S h} \times 100 \%$

Keterangan:

$\boldsymbol{V}_{\boldsymbol{a}}=$ Validator ahli

$\boldsymbol{T S} \boldsymbol{e}=$ Total skor empiris dari validator

$\boldsymbol{T S h}=$ Total skor maksimal yang diharapkan

Untuk mengetahui hasil akhir validasi silabus, RPP dan LKPD dari para ahli maka dihitung dengan menggunakan rumus rata-rata (mean). Untuk mengetahui kriteria kevalidan dapat dilihat pada Tabel 1 berikut.

Tabel 1. Kriteria Kevalidan Perangkat Pembelajaran

\begin{tabular}{|c|c|}
\hline Interval & Kategori \\
\hline $85,01 \%-100,00 \%$ & Sangat valid \\
\hline $70,01 \%-85,00 \%$ & Valid \\
\hline $50,01 \%-70,00 \%$ & Kurang valid \\
\hline $01,00 \%-50,00 \%$ & Tidak valid \\
\hline
\end{tabular}

Sumber: (Akbar, 2013)

Data kepraktisan perangkat pembelajaran diperoleh dari angket respon peserta didik. Analisis data hasil dari angket respon peserta didik menggunakan rumus sebagai berikut.

$\boldsymbol{R}=\frac{\sum \boldsymbol{P}}{\text { jumlah peserta didik }}$

Keterangan:

$\boldsymbol{R}:$ Hasil akhir respon peserta didik

$\sum \boldsymbol{P}:$ Jumlah persentase kepraktisan

Nilai yang diperoleh kemudian diinterpretasikan dengan kategori kepraktisan Tabel 2 berikut.

Tabel 2. Kriteria Kepraktisan Perangkat Pembelajaran

\begin{tabular}{|c|c|}
\hline Interval & Kategori \\
\hline $85,01 \%-100,00 \%$ & Sangat Praktis \\
\hline $70,01 \%-85,00 \%$ & Praktis \\
\hline $50,01 \%-70,00 \%$ & Kurang Praktis \\
\hline $01,00 \%-50,00 \%$ & Tidak Praktis \\
\hline
\end{tabular}

Sumber: (Akbar, 2013)

\section{HASIL}

Penelitian pengembangan bertujuan untuk menghasilkan suatu produk berupa perangkat 
Pengembangan Perangkat Pembelajaran Matematika Berbasis Model Problem Based Learning Untuk Memfasilitasi Kemampuan Komunikasi Matematis Peserta Didik Kelas VII SMP/MTs, Aisyah Nurul Rahmah, Zulkarnain, Nahor Murani Hutapea

pembelajaran matematika. Perangkat yang dikembangkan adalah perangkat pembelajaran matematika dengan model problem based learning untuk meningkatkan kemampuan komunikasi matematis peserta didik pada materi segiempat dan segitiga kelas VII SMP/MTs. Perangkat pembelajaran yang peneliti kembangkan ini dirancang menggunakan model 4-D dengan empat tahapan yaitu tahap define (pendefinisian), tahap design (perancangan), tahap develop (pengembangan), tahap disseminate (penyebaran). Namun, pada penelitian ini, tahap develop (pengembangan) yang peneliti lakukan hanya sampai pada ujicoba kelompok kecil untuk melihat kepraktisan perangkat pembelajaran yang dikembangkan.

Pada tahap define peneliti melakukan analisis awal akhir dengan melakukan wawancara kepada beberapa guru dimana peneliti menemukan masalah yaitu adanya guru yang belum mengembangkan perangkat, namun ada beberapa guru yang telah mengembangkan perangkat, namun dalam perangkat yaitu RPP guru belum mencantumkan seluruh komponen yang ada pada standar proses yaitu kegiatan pembelajaran belum memperlihatkan proses pembelajaran pada kurikulum 2013, tidak menggunakan metode/model pembelajaran yang bervariasi, serta pada RPP tidak terdapat penilaian yang akan dilakukan setelah proses pembelajaran. LKPD yang digunakan peserta didik berasal dari penerbit, hal ini dikarenakan ketidakpahaman dan keterbatasan waktu yang dimiliki guru dalam merancang LKPD. LKPD ini hanya berisi kumpulan materi serta soal-soal yang harus dikerjakan peserta didik. LKPD tersebut tidak memuat tahapan terstruktur yang dapat membantu peserta didik dalam menemukan konsep untuk menyelesaikan persoalan yang diberikan.

Analisis peserta didik, peneliti memperoleh informasi bahwa peserta didik kelas VII SMP yang berusia rata-rata 12-13 tahun. Peserta didik tersebut termasuk kedalam kelompok masa remaja. Menurut teori Piaget kemampuan intelektual remaja telah sampai pada fase operasional formal, peserta didik umumnya sudah mampu bernalar, berpikir secara luas dan mengkonstruksi pengetahuannya sendiri. Peneliti melakukan studi pendahuluan dengan memberikan soal kemampuan komunikasi matematis pada materi segiempat dan segitiga untuk melihat perkembangan kognitif peserta didik. Analisis materi, peneliti mengidentifikasi materi-materi yang akan dikembangkan. Penelitian ini peneliti memilih materi segiempat dan segitiga dengan KD 3.11 dan KD 4.11. Peneliti menyusun rencana kegiatan pembelajaran menjadi 7 pertemuan. Analisis tugas, peneliti menganalisis tugas-tugas berupa kompetensi yang akan dikembangkan dalam kegiatan pembelajaran. Analisis tugas dilakukan dengan cara menelaah dokumen dan studi literatur terhadap KI dan KD yang akan dikembangkan. Perumusan tujuan pembelajaran, dilakukan untuk mengetahui kajian yang digunakan dalam menyusun silabus, RPP dan LKPD pada materi segiempat dan segitiga.

Tahap design, peneliti menyiapkan format awal perangkat pembelajaran berupa Silabus, RPP dan LKPD dan tes kemampuan komunikasi matematis peserta didik.. Rancangan silabus dan RPP yang disusun berdasarkan Permendikbud Nomor 22 Tahun 2016 menggunakan model problem based learning . Sedangkan untuk rancangan LKPD disusun berdasarkan langkah-langkah model problem based learning . 
Hasil analisis perangkat pembelajaran menunjukkan silabus yang dirancang terdiri dari komponen $\mathrm{KD}$, materi pembelajaran, dan kegiatan pembelajaran untuk tujuh pertemuan pada materi keliling dan luas segiempat dan segitiga yang memuat komponen identitas, KI, KD, materi pembelajaran, indikator pencapaian kompetensi, kegiatan pembelajaran, penilaian, alokasi waktu, dan sumber belajar. Peneliti merancang RPP pada materi keliling dan luas segiempat dan segitiga untuk tujuh kali pertemuan yang masing-masing memuat komponen identitas; KI; KD dan indikator pencapaian kompetensi; tujuan pembelajaran; materi pembelajaran; pedekatan, model, dan metode pembelajaran; media, alat, dan sumber belajar; langkah-langkah pembelajaran; dan penilaian. Peneliti merancang LKPD dengan menerapkan model problem based learning, sehingga dapat memfasilitasi peserta didik dalam melakukan penyelidikan yang terdiri dari bagian sampul, isi LKPD dan latihan soal awal berisi sampul LKPD, bagian isi berisi lembar aktivitas, dan bagian kesimpulan/ akhir berisi latihan soal.

Pada tahap develop (pengembangan) perangkat pembelajaran yang sudah di rancang berdasarkan format kemudian dikembangkan. Kegiatan pembelajaran memuat tahapan model problem based learning dengan pendekatan saintifik, yaitu orientasi siswa kepada masalah dengan (mengamati), mengorganisasikan siswa belajar (menanya), membimbing penyelidikan individu dan kelompok (mengumpulkan informasi, dan menalar), mengembangkan dan menyajikan hasil karya (mengkomunikasikan), dan menganalisa dan mengevaluasi proses pemecahan masalah. Berikut contoh kegiatan pembelajaran pada silabus dan RPP yang telah dikembangkan.

\begin{tabular}{|c|c|c|c|c|c|c|}
\hline Kompetensi Dasar & $\begin{array}{l}\text { Materi } \\
\text { Pokok/Materi } \\
\text { Pembelajaran }\end{array}$ & $\begin{array}{l}\text { Indikator Pencapaian } \\
\text { Kompetensi } \\
\text { (IPK) }\end{array}$ & Kegiatan Pembelajaran & Penilaian & $\begin{array}{l}\text { Alokasi } \\
\text { Waktu }\end{array}$ & $\begin{array}{l}\text { Sumber } \\
\text { Belajar }\end{array}$ \\
\hline $\begin{array}{l}\text { 3.11 Mengaitkan rumus } \\
\text { keliling dan luas } \\
\text { untuk berbagai } \\
\text { jenis segi empat } \\
\text { (persegi, persegi } \\
\text { panjang, belah } \\
\text { ketupat, jajar } \\
\text { genjang, } \\
\text { trapesium, dan } \\
\text { layang-layang) } \\
\text { dan segitiga } \\
\text { 4.11 Menyelesaikan } \\
\text { masalah } \\
\text { kontekstual yang } \\
\text { berkaitan dengan } \\
\text { luas dan keliling } \\
\text { segiempat } \\
\text { (persegi, persegi } \\
\text { panjang, belah } \\
\text { ketupat, jajar } \\
\text { genjang, } \\
\text { trapesium, dan } \\
\text { layang-layang) } \\
\text { dan segitiga }\end{array}$ & $\begin{array}{l}\text { Persegi panjang } \\
\text { - Sifat-sifat } \\
\text { - Keliling } \\
\text { - Luas }\end{array}$ & $\begin{array}{l}\text { 3.11.1 Menentukan sifat- } \\
\text { sifat persegi panjang } \\
\text { 3.11.2 Menemukan rumus } \\
\text { keliling dan luas } \\
\text { persegi panjang } \\
\text { 3.11.3 } \begin{array}{l}\text { Menghitung keliling } \\
\text { dan luas persegi } \\
\text { panjang }\end{array} \\
\text { 4.11.1 Menyelesaikan } \\
\text { masalah kontekstual } \\
\text { yang berkaitan } \\
\text { dengan keliling dan } \\
\text { luas persegi panjang } \\
\text { menggunakan } \\
\text { kemampuan } \\
\text { komunikasi }\end{array}$ & $\begin{array}{l}\text { Peserta didik melalui diskusi kelompok } \\
\text { menggunakan langkah-langkah problem based } \\
\text { learning melakukan aktivitas-aktivitas berikut: } \\
\text { Fase 1 : orientasi siswa kepada masalah } \\
\text { Mengamati } \\
\text { - Mengamati permasalahan yang berbentuk soal } \\
\text { cerita yang tertera pada LKPD-1 tentang } \\
\text { keliling dan luas persegi panjang } \\
\text { Fase 2: Mengorganisasikan siswa belajar } \\
\text { Menanya } \\
\text { - Menentukan apa yang diketahui dan apa yang } \\
\text { ditanya dari permasalahan yang ada pada } \\
\text { LKPD-1. } \\
\text { Fase 3: Membimbing Penyelidikan Individu dan } \\
\text { Kelompok } \\
\text { Mengumpulkan Informasi } \\
\text { - Menemukan rumus keliling dan luas persegi } \\
\text { panjang untuk menyelesaikan permasalahan } \\
\text { yang berbentuk soal cerita yang ada pada } \\
\text { LKPD-1. } \\
\text { Menalar/Mengasosiasi } \\
\text { - Menyelesaikan permasalahan pada masalah } 1 \\
\text { yang terdapat pada LKPD-1. }\end{array}$ & $\begin{array}{l}\text { Pengetahuan } \\
\text { - Jenis: Tes } \\
\text { Teknik: Tes lisan } \\
\text { dengan jawaban } \\
\text { singkat. } \\
\text { Bentuk instrumen: } \\
\text { Pertanyaan } \\
\text { langsung yang } \\
\text { berkaitan dengan } \\
\text { keliling dan luas } \\
\text { persegi panjang } \\
\text { - Jenis: Tes } \\
\text { Teknik: Tes tertulis } \\
\text { bentuk instrumen: } \\
\text { uraian yang } \\
\text { berkaitan dengan } \\
\text { keliling dan luas } \\
\text { persegi panjang } \\
\end{array}$ & $3 \times 40^{\prime}$ & $\begin{array}{l}\text { - Lembar } \\
\text { Kerja } \\
\text { Peserta } \\
\text { Didik } \\
\text { (LKPD-1) } \\
\text { tentang } \\
\text { keliling dan } \\
\text { luas persegi } \\
\text { panjang }\end{array}$ \\
\hline
\end{tabular}


Pengembangan Perangkat Pembelajaran Matematika Berbasis Model Problem Based Learning Untuk Memfasilitasi Kemampuan Komunikasi Matematis Peserta Didik Kelas VII SMP/MTs, Aisyah Nurul Rahmah, Zulkarnain, Nahor Murani Hutapea

Gambar 1. Gambaran Silabus

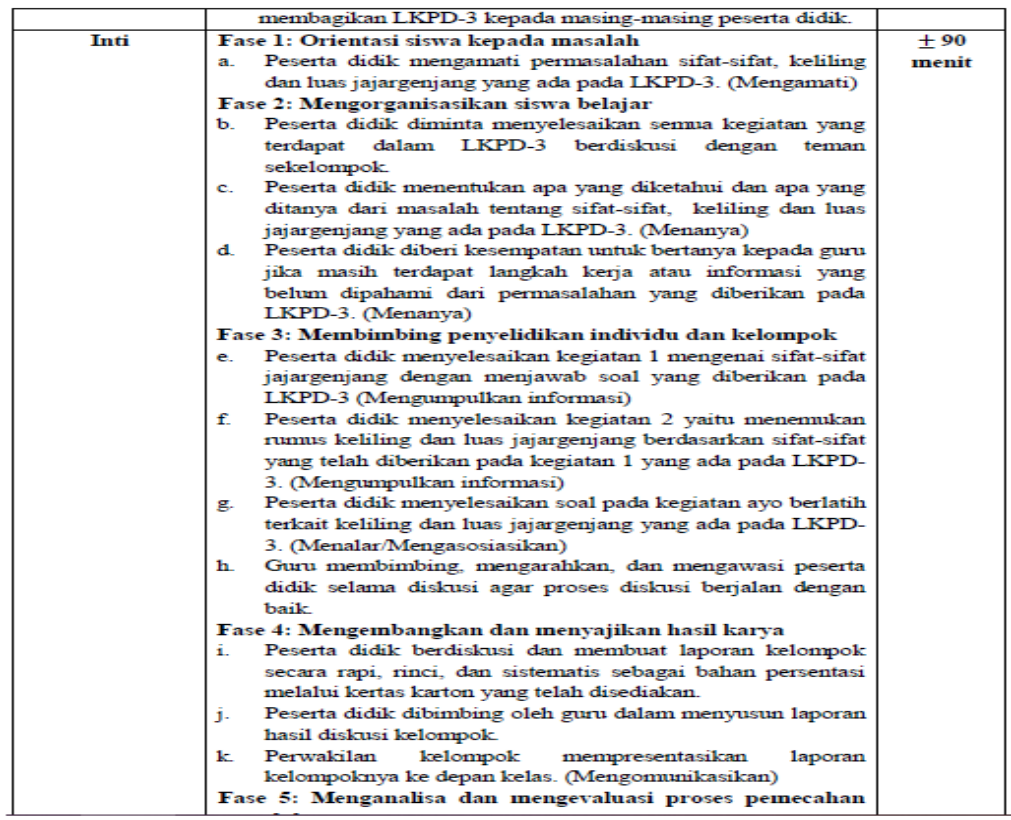

Gambar 2. Kegiatan Inti pada RPP

LKPD dikembangkan dengan menerapkan langkah model problem based learning dan pendekatan saintifik pada materi segiempat dan segitiga kelas VII SMP/MTs. Permasalahan yang diberikan pada LKPD menggunakan soal kontekstual. Kegiatan pada LKPD disusun secara rinci, sehingga dapat membantu peserta didik untuk menemukan konsep dari materi yang dipelajari. LKPD didesain dengan warna yang menarik agar peserta didik tertarik dalam mengikuti kegiatan pembelajaran. Hasil Rancangan LKPD terdiri dari halaman sampul, isi LKPD dan latihan soal. Halaman sampul LKPD yang dikembangkan memuat judul, identitas peserta didik, gambar, materi pembelajaran, tujuan serta petunjuk penggunaan LKPD. Kegiatan pembelajaran pada bagian isi LKPD dirancang untuk membantu peserta didik dalam menemukan konsep dari materi yang dipelajari bersama kelompoknya. Isi LKPD diawali dengan pemberian soal cerita kontekstual. Bagian isi LKPD disusun berdasarkan langkah model problem based learning dengan pendekatan saintifik. Berikut ini contoh bagian sampul dan bagian isi LKPD yang telah dikembangkan.

Rancangan LKPD pada Gambar 3 merupakan rancangan bagian sampul dan bagian isi LKPD yaitu langkah orientasi pada masalah pada materi keliling dan luas persegi panjang. Langkah orientasi siswa pada masalah disajikan kolom "mengamati masalah". Pada tahap ini kegiatan dalam LKPD dimulai dengan memberikan permasalahan berbentuk soal cerita kontekstual terkait materi keliling dan luas persegi panjang. Kemudian pada tahap mengorganisasi peserta didik disajikan kolom "menanya". Pada tahap ini peserta didik menuangkan pemahaman mereka tentang masalah dengan menuliskan yang diketahui dan ditanya. Guru memfasilitasi peserta didik dalam memahami masalah yang diberikan.

Selanjutnya, langkah membimbing penyelidikan terdapat kegiatan "mengumpulkan informasi", 
peserta didik diminta untuk mengerjakan kegiatan-kegiatan yang terkait permasalahan yang diberikan. Selanjutnya disajikan kolom "menalar" untuk menentukan penyelesaian dari permasalahan yang diberikan. Pada tahap ini peserta didik diminta untuk menyelesaikan kegiatan "ayo berlatih", peserta didik menyelesaikan soal-soal cerita konstektual yang diberikan. Langkah menyajikan hasil karya disajikan kolom berisi perintah kepada peserta didik. Langkah mengevaluasi proses pemecahan masalah disajikan kolom berisi perintah kepada peserta didik.

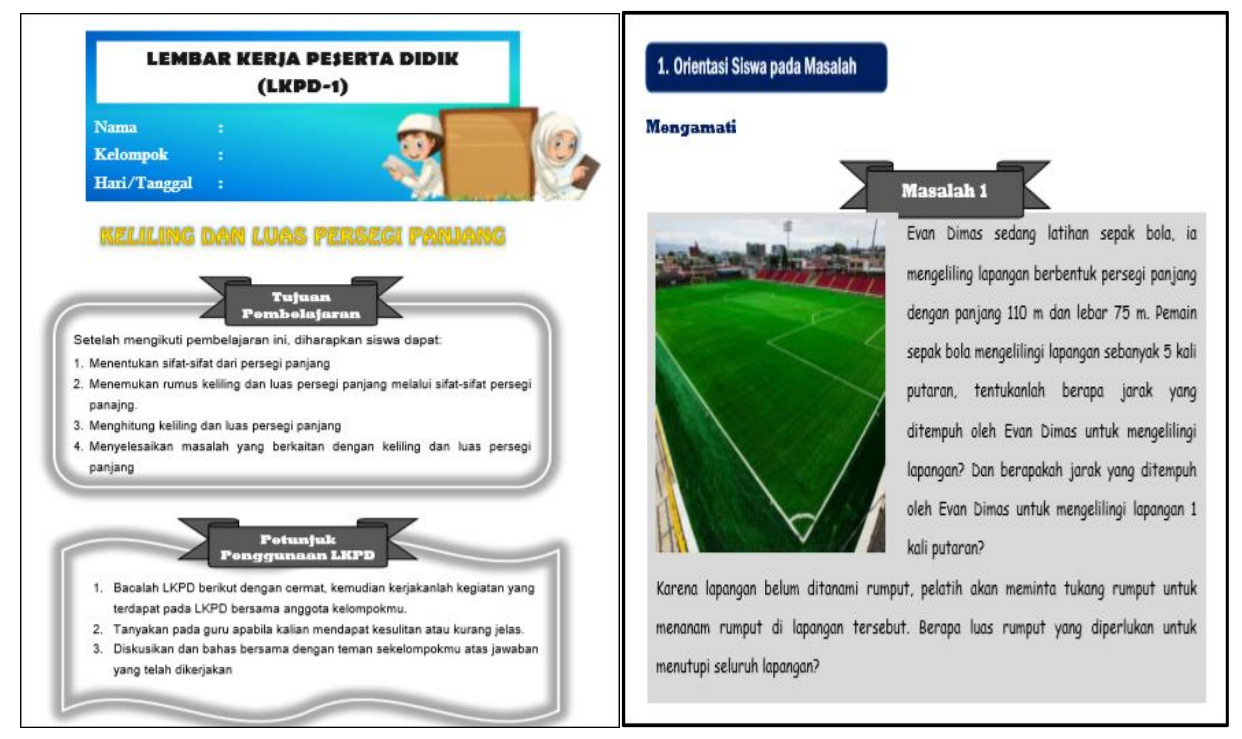

Gambar 3. Bagian Sampul dan Langkah Orientasi pada Masalah

Perangkat pembelajaran yang sudah dikembangkan di validasi kepada validator serta melakukan uji coba terhadap perangkat yang telah disusun. Saran-saran dari validator tersebut akan dijadikan bahan untuk merevisi perangkat yang telah disusun. Hasil revisi tersebut merupakan perangkat pembelajaran yang telah memenuhi kriteria valid. Perangkat pembelajaran yang telah dinyatakan valid diuji coba terhadap peserta didik. Pada penelitian ini, uji coba dilakukan hanya sampai pada uji coba kelompok kecil untuk melihat kepraktisan perangkat pembelajaran yang dikembangkan. Uji coba ini dilakukan terhadap 8 orang peserta didik kelas VII SMP Yabri Pekanbaru. Rata-rata penilaian yang diberikan oleh tiga orang validator terhadap perangkat pembelajaran yang dikembangkan berupa silabus, RPP dan LKPD serta soal dapat dilihat pada Tabel 3 s/d Tabel 5 berikut.

Tabel 3. Hasil Validasi Silabus 
Pengembangan Perangkat Pembelajaran Matematika Berbasis Model Problem Based Learning Untuk Memfasilitasi Kemampuan Komunikasi Matematis Peserta Didik Kelas VII SMP/MTs, Aisyah Nurul Rahmah, Zulkarnain, Nahor Murani Hutapea

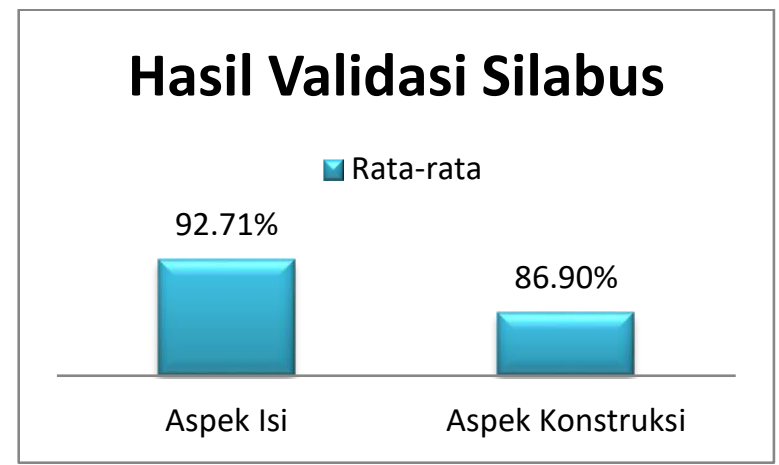

Secara keseluruhan rata-rata skor validasi untuk silabus adalah 89,81\% dengan kategori sangat valid sehingga silabus yang dikembangkan sudah sesuai dengan komponen silabus dalam Permendikbud Nomor 22 Tahun 2016. Adapun hasil validasi RPP oleh validator adalah sebagai berikut.

Tabel 4. Hasil Validasi RPP

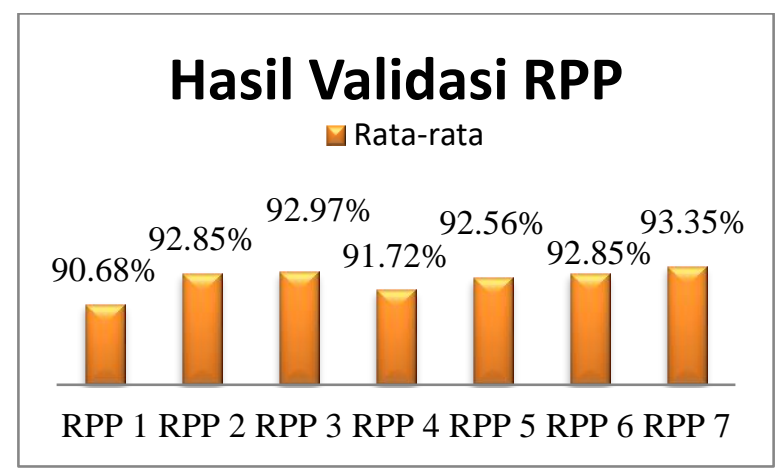

Secara keseluruhan rata-rata keseluruhan hasil validasi RPP oleh validator yang diperoleh yaitu 92,43\% dengan kategori "sangat valid", artinya perangkat pembelajaran dengan model problem based learning yang dikembangkan sudah sesuai dengan komponen RPP dalam Permendikbud Nomor 22 Tahun 2016. Adapun hasil validasi LKPD adalah sebagai berikut.

Tabel 5. Hasil Validasi LKPD

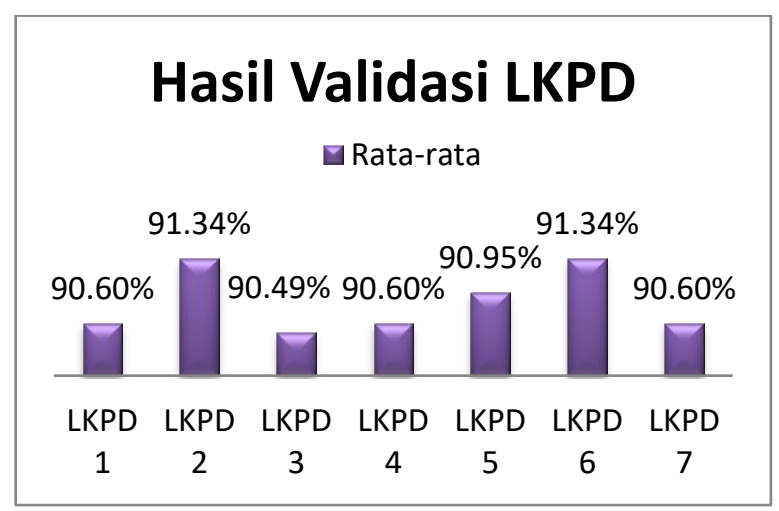

Secara keseluruhan rata-rata hasil validasi LKPD oleh validator 90,85\% dengan kategori "sangat valid", artinya LKPD yang dikembangkan telah memuat langkah-langkah problem based learning dan difasilitasi untuk mengembangkan kemampuan komunikasi matematis peserta didik. Setelah 
perangkat pembelajaran di validasi dan hasil validasi menunjukkan kategori sangat valid, kemudian lanjut ke tahap berikutnya yaitu tahap uji coba. Tahap uji coba kelompok kecil, peneliti melakukan uji coba untuk melihat keterbacaan dan kepraktisan dari LKPD yang telah dikembangkan. Peneliti melakukan uji coba terhadap delapan siswa dengan kemampuan heterogen. Adapun hasil kepraktisan dari uji coba terbatas adalah sebagai berikut.

Tabel 6. Hasil Kepraktisan LKPD

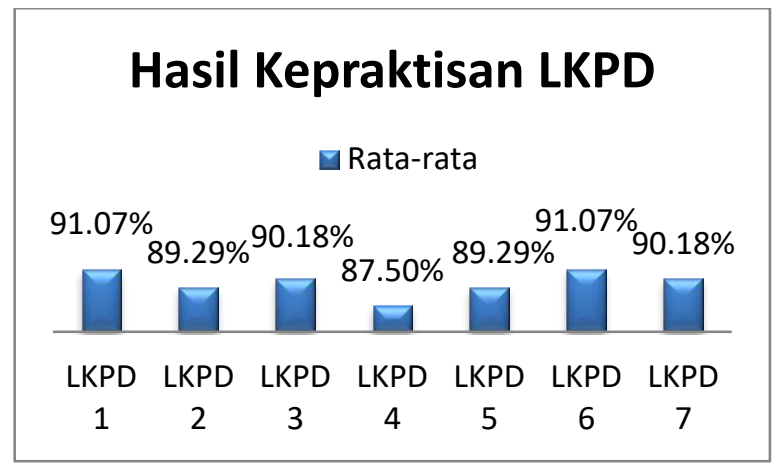

Berdasarkan hasil dari uji coba kepraktisan diperoleh nilai rata-rata persentase dari angket respon peserta didik mencapai $89,80 \%$ dengan kategori sangat praktis, artinya LKPD sudah dapat dipahami oleh peserta didik dari segi masalah yang diberikan, kalimat perintah dalam melakukan kegiatan dan soal latihan. Adapun tahapan selanjutnya yang dilakukan peneliti adalah tahap disseminate.

Adapun revisi silabus pada saat validasi yaitu salah satu validator menyarankan agar menguraikan langkah-langkah pembelajaran dengan menggunakan pendekatan saintifik pada kegiatan pembelajaran dalam silabus. Selanjutnya revisi RPP selama validasi yaitu: (1) validator menyarankan agar tujuan dan motivasi disesuaikan dengan IPK; (2) validator menyarankan agar memperbaiki pedoman penskoran pada RPP.

Revisi LKPD yang disarankan validator yaitu: (1) validator menyarankan untuk memperbaiki redaksi pada masalah 1 yang ada pada LKPD 1 dan menambahkan gambar sesuai redaksi; (2) validator menyarankan untuk memperbaiki bahasa pada kegiatan menanya diganti sesuai saran; (3) validator menyarankan gambar dan redaksi soal no 4 pada LKPD 4 telah disamakan sesuai saran dari validator. 
Pengembangan Perangkat Pembelajaran Matematika Berbasis Model Problem Based Learning Untuk Memfasilitasi Kemampuan Komunikasi Matematis Peserta Didik Kelas VII SMP/MTs, Aisyah Nurul Rahmah, Zulkarnain, Nahor

\section{KESIMPULAN}

Berdasarkan hasil analisis data dan pembahasan diperoleh kesimpulan sebagai berikut: 1) Hasil pengembangan perangkat pembelajaran berbasis model problem based learning berupa silabus, RPP, dan LKPD menunjukkan bahwa layak digunakan dan termasuk dalam kategori sangat baik dan praktis. 2) Hasil akhir dari penelitian pengembangan ini adalah tersusun produk berupa silabus, RPP, dan LKPD dengan model problem based learning yang dapat memfasilitasi kemampuan komunikasi matematis peserta didik.

\section{UCAPAN TERIMA KASIH}

Terima kasih kami ucapkan kepada Bapak/Ibu Kepala Sekolah, Majelis Guru SMP Yabri Pekanbaru yang sudah bersedia memberikan izin kepada penulis, kepada Bapak Zulkarnain, dan Ibu Nahor Murani Hutapea yang telah membimbing dan mengarahkan penulis dalam melaksanakan penelitian dan penulisan artikel ilmiah ini.

\section{REFERENSI}

Akbar, S. (2013). Instrumen Perangkat Pembelajaran. PT Remaja Rosdakarya: Bandung.

Apriana, R., Sugiatno, \& Hamdani. (2015). Pengembangan LKS Berstruktur Project Based Learning untuk Meningkatkan Kemampuan Komunikasi Matematis di Madrasah Aliyah Negeri. Jurnal Pendidikan Dan Pembelajaran, 5(1).

Armis, \& Suhermi. (2017). Pengembangan Perangkat Pembelajaran Matematika Berbasis Problem Based Learning untuk Siswa Kelas VII Semester 1 SMP / MTs Materi Bilangan dan Himpunan. Al- Khwarizmi: Jurnal Pendidikan Matematika Dan Ilmu Pengetahuan Alam, 5(1), 25-42.

Fatmasuci, F. W. (2017). Pengembangan Perangkat Pembelajaran Berbasis Masalah Berorientasi pada Kemampuan Komunikasi dan Prestasi Belajar Matematika Siswa SMP. Jurnal Riset Pendidikan Matematika, 4(1), 32-42.

Fitri, M., Yuanita, P., \& Maimunah. (2020). Pengembangan Perangkat Pembelajaran Matematika Terintegrasi Keterampilan Abad 21 Melalui Penerapan Model Problem Based Learning (PBL). Jurnal Gantang, 5(1), 77-85.

Fitriani, M., Hartono, Y., \& Purwoko. (2010). Pengembangan Perangkat Pembelajaran Matematika dengan Pendekatan Kuantum di Kelas VIII SMP. Jurnal Pendidikan Matematika, 4(1), 53-69.

Frisnoiry, S., Armanto, D., \& Sumarno. (2014). Pengembangan Perangkat Pembelajaran Melalui Pendekatan Matematika Realistik. Jurnal Pendidikan Matematika PARADIKMA, 7(1), 47-58.

Hikmah, A., Roza, Y., \& Maimunah. (2019). Analisis Kemampuan Komunikasi Matematis Siswa SMP pada Soal SPLDV. Media Pendidikan Matematika, 7(1), 29-35.

Noviyana, I. N., Dewi, N. R., \& Rochmad. (2019). Analisis Kemampuan Komunikasi Matematis 
Siswa Ditinjau dari Self-Confidence. PRISMA: Prosiding Seminar Nasional Matematika, 2, 704-709.

Pansa, H. E. (2017). Pengembangan LKPD dengan Model Problem Based Learning untuk Meningkatkan Kemampuan Komunikasi Matematis Siswa. Prosiding: Seminar Nasional Matematika Dan Pendidikan Matematika, 229-238.

Peraturan Menteri Pendidikan dan Kebudayaan Nomor 22 Tahun 2016: Standar Proses Pendidikan Dasar dan Menengah. Diakses 20 April 2020.

Putra, F. G. (2016). Pengaruh Model Pembelajaran Reflektif dengan Pendekatan Matematika Realistik Bernuansa Keislaman terhadap Kemampuan Komunikasi Matematis. Al-Jabar: Jurnal Pendidikan Matematika, 7(2), 203-210.

Radeswandri. (2016). Pengembangan Perangkat Pembelajaran Matematika Berbasis Problem Based Learning (PBL) pada Materi Bilangan Bulat. Suara Guru: Jurnal Ilmu Pendidikan Sosial, Sains, Dan Humaniora, 2(2), 101-110.

Rianti, R., Saragih, S., \& Zulkarnain. (2020). Development of Mathematics Learning Tools in the Context of Riau Malay Culture to Improve Students Mathematical Problem Solving Ability. Journal of Educational Sciences, 4(1), 73-82.

Ridwan, R., Zulkardi, \& Darmawijoyo. (2016). Pengembangan Perangkat Pembelajaran Aritmatika Sosial Berbasis Problem Based Learning di Kelas VII SMP. Jurnal Elemen, 2(2), 92-115.

Sari, L. S. P., \& Rahadi, M. (2014). Pembelajaran Berbasis Masalah untuk Meningkatkan Kemampuan Komunikasi Matematika Siswa Sekolah Menengah Pertama. Jurnal Pendidikan Matematika, 3(3), 143-150.

Tanjung, H. S., \& Nababan, S. A. (2018). Pengembangan Perangkat Pembelajaran Matematika Berorientasi Model Pembelajaran Berbasis Masalah (PBM) Untuk Meningkatkan Kemampuan Berpikir Kritis Peserta didik SMA Se-Kuala Nagan Raya Aceh. Genta Mulia: Jurnal Ilmiah Pendidikan, 9(2), 56-70.

Trianto. (2009). Mendesain model pembelajaran inovatif-progresif. Kencana Prenada Media Group: Jakarta.

Yustianingsih, R., Syarifuddin, H., \& Yerizon. (2017). Pengembangan Perangkat Pembelajaran Matematika Berbasis Problem Based Learning (PBL) untuk Meningkatkan Kemampuan Pemecahan Masalah Peserta Didik Kelas VIII. JNPM (Jurnal Nasional Pendidikan Matematika), 1(2), 258-274. 